\title{
'Seeing through touch': the material world of visually impaired children ${ }^{1}$
}

\section{"Vendo através do toque": o mundo material das crianças com deficiência visual}

\author{
Ian Grosvenor ${ }^{2}$ \\ Natasha Macnab ${ }^{2}$
}

\begin{abstract}
This article examines the changing material world of the visually impaired child and the ways in which this has been viewed and understood by scholars, philosophers, educators and other commentators over time. It describes and analyses tactile encounters as they have been planned for by educators, museum curators and others, from the Age of the Enlightenment until the present day. It takes as its starting point a recent blog that appeared online in 2011, which posted images from handling sessions for the visually impaired child, organized by John Alfred Charlton Deas from Sunderland Museum, England, between 1913-1926. It traces the provenance and development of ideas around 'seeing through touch', from the embossed books and maps and the printing machines for systems such as Braille in the nineteenth century to the theoretical and pedagogical developments which began to occur at the start of the twentieth century.
\end{abstract}

Keywords: culture material; museum; blindness; visually impaired children.

\section{RESUMO}

Este artigo analisa as mudanças no mundo material da criança com deficiência visual e as formas como ela foi vista e entendida ao longo do tempo por estudiosos, filósofos, educadores e outros comentaristas. Ele descreve e analisa como os encontros táteis, desde o Iluminismo até os dias de hoje

1 The authors would like to thank Tyne and Wear Archives and Museum and for permission to reproduce the Sunderland Museum photographs and the Museum Association for providing information on J.A. Charlton Deas. 2TT, UK.

${ }^{2}$ University of Birmingham (UB). School of Education. Edgbaston, Birmingham. B15 
foram planejados, dentre outros, por educadores e curadores de museus. $\mathrm{O}$ ponto de partida desta análise é a publicação na internet de um blog, em 2011, onde estão postadas imagens organizadas por John Alfred Chalton (Sunderland Museum, Inglaterra), entre os anos de 1913-1926; e segue delineando a origem e o desenvolvimento de ideias em torno do "ver através do tato", tomando o exemplo dos livros e mapas em alto relevo e das máquinas de impressão, como as do sistema Braille no século XIX, aos desenvolvimentos teóricos e pedagógicos que se iniciam no século XX.

Palavras-chave: cultura material; museu; cegueira; criança com deficiência visual.

'... it is so perfect and so exact that one might almost say that they [the blind] see with their hands.'

(René Descartes, 1637)

'To him, his fingers are eyes' (John Alfred Charlton Deas, 1913)

In May 2011 a 'blog' appeared on the Tyne and Wear Museum and Archive website about the work of John Alfred Charlton Deas at Sunderland Museum, England. The text was accompanied by seven photographs. Additional photographs were posted by Tyne and Wear on Pinterest.com, an online 'pinboard.' A single image from the same collection of photographs appeared on Wikipedia in July 2011. In August 2011 the website www.Retronaunt displayed the same photographs as on Pinterest.com under the heading 'Seeing through touch' 1913-1926, but with very little additional text. All of the photographs and other related images could also be found on flicrk.com, and a selection of the images on the Disability Studies website, at Temple University, Philadelphia, on www. publicdomanreview, www.tumblr.com and www.blindnessandarts. All the photographs related to Deas' organising of handling sessions for visually impaired children and adults at Sunderland Museum in the early twentieth century.

In recent years sensory history has emerged as a research topic of growing interest to historians and has been accompanied by a call to incorporate the senses into our understanding of the past (SMITH, 2012). ${ }^{3}$ In parallel, but not necessarily connected with the 'sensory turn' in history there has also emerged a 'new disability history' (KUDLICK, 2003) and a new research agenda around material culture. This essay's starting point is Deas' handling sessions and it uses

3 Mark. M. Smith, Sensory History (BERG, 2007) Historians of education and childhood have been slow to engage with the sensory research agenda, see Grosvenor (2012). 
his experiments in learning through touch to offer some insights into the material world of the visually impaired child and, in this sense, is also a contribution to the new disability history. The essay ends by offering some brief reflections on the materiality of photographs and the ever expanding virtual archive which is the World Wide Web.

In contemporary educational research it is not uncommon to refer to 'visual impairment' ${ }^{4}$ rather than blindness, hence the reference in the title and the abstract of this article. However, the words 'blind' and 'blindness' are used throughout the body of the text as they are reflective of the discourses in use in the period covered by this study.

\section{'What the Blind May See or Experiments in Tactile Sight'}

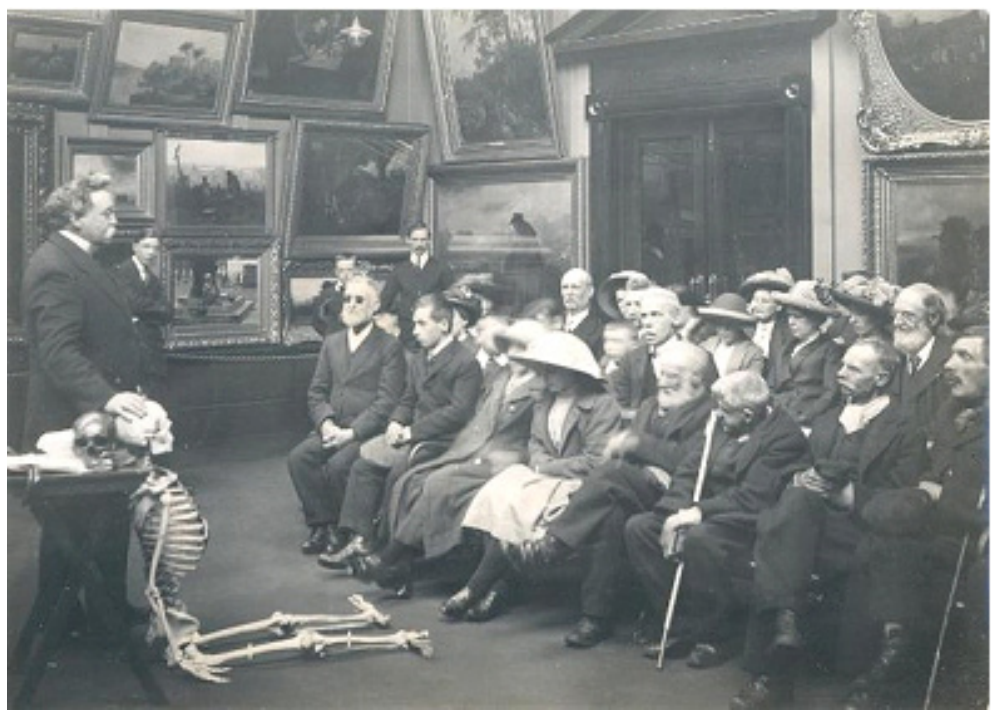

FIGURE 1 - BLIND ADULTS LISTENING TO A SHORT LECTURE AT SUNDERLAND MUSEUM BEFORE EXAMINING A HUMAN SKELETON, 1913.

SOURCE: Copyright Tyne and Wear Archives and Museums

In July 1913 J. A. Charlton Deas, Librarian and Chief Director of Sunderland Public Libraries, Museum and Art Gallery read a paper at the Museum

\footnotetext{
${ }^{4}$ See, for example, The British Journal for Visual Impairment.
} 
Association conference in Hull on the theme of 'The Showing of Museums and Art Galleries to the Blind'. The talk was illustrated with photographs, lantern slides and a selection of models made by children. It described in detail experiments he had undertaken in the museum to help alleviate 'the long night of those who live in perpetual darkness.' Deas initially had focused his attention on working with the adult blind and organized five handling sessions accompanied by related lectures. The sessions lasted three hours and took place on Sunday afternoons when the museum was closed to the general public and 'the privacy desirable for such experiments was thereby secured.' The focus of the first tactile session was the art gallery, but began with a description of the 'dimensions and arrangements' of the art gallery. The length and breadth of the room was given in the number of paces, the height of the room, the lighting arrangements, the method of hanging and protecting the pictures were also described. Deas commented:

[...] these details may at first seem trivial, but a knowledge of surroundings, relative proportions and "atmosphere" generally, is as important and interesting to the sightless as to the sighted, who are apt to overlook the fact through unconscious familiarity (DEAS, 1913).

The participants were then given a small painted and unpainted canvas, an artist's palette, brushes, and paint tubes to 'feel and examine'. The use of all of these was explained and then the participants were taken into the gallery and presented with some glazed images, which were examined for size, the content of the painting was described, and the most important features were indicated 'by guiding the first finger of the person's hand over the outlines.' The subsequent demonstrations after the 'Picture Sunday' were taken up with handling museum objects from the Natural History collection along with listening to contextual lectures. A final session consisted of handling miscellaneous objects including a 'Burmese Idol', prehistoric implements, armour, Zulu Shields, models of different types of ships, a model of a Locomotive and 'Busts of Celebrated Men.' The same programme was then introduced for blind children from the Council School on consecutive Monday mornings when the museum was closed for three hours. The children used their hands with 'great dexterity', which occasioned Deas to remark in his lecture that 'touch is the first sense which a child develops' and to quote Maria Montessori's comment that her blindfolded children were 'proud of "seeing" without eyes' and holding up their hands and crying 'Here are my eyes, I can see with my hands.' 


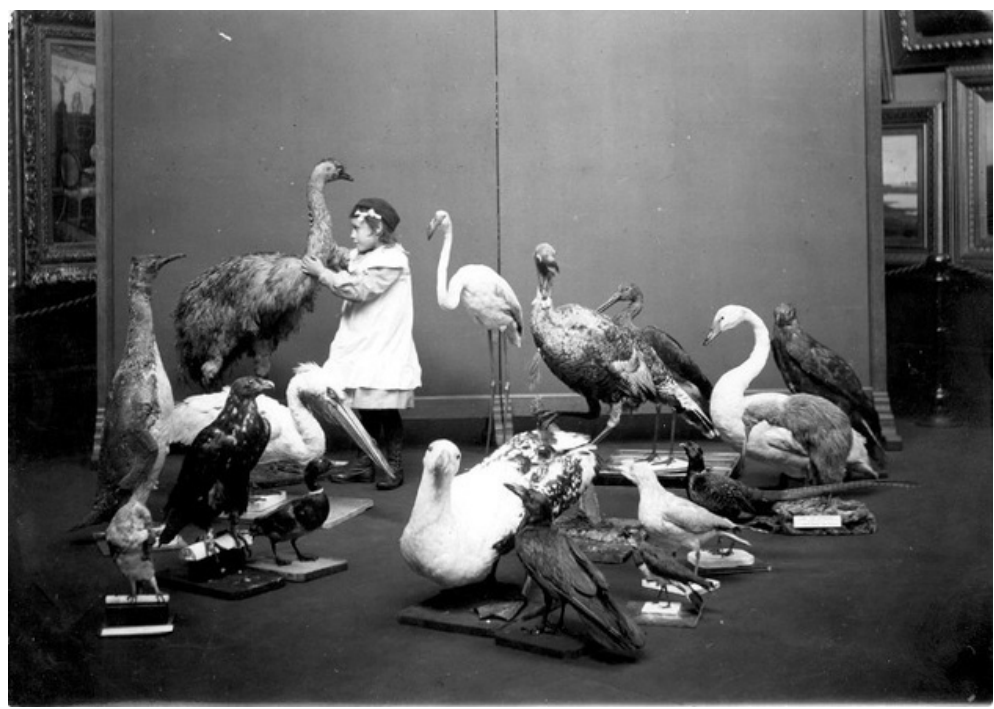

FIGURE 2 - A BLIND GIRL EXAMINING MOUNTED BIRDS

SOURCE: Copyright Tyne and Wear Archives and Museums.

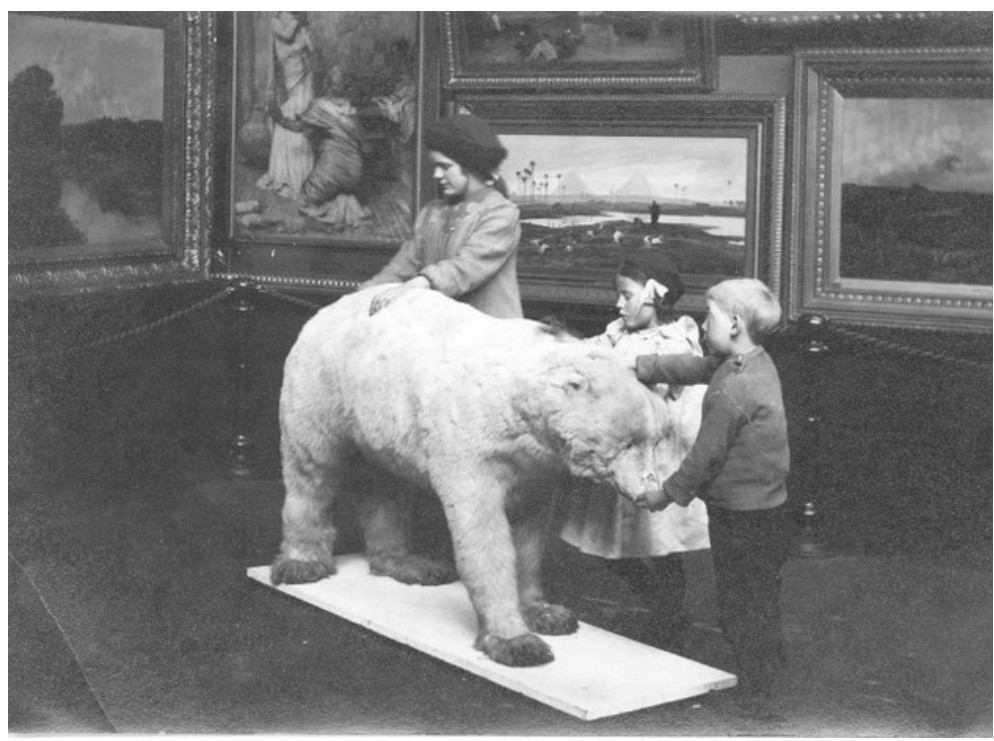

FIGURE 3 - THREE BLIND CHILDREN EXAMINING A MOUNTED POLAR BEAR SOURCE: Copyright Tyne and Wear Archives and Museums. 


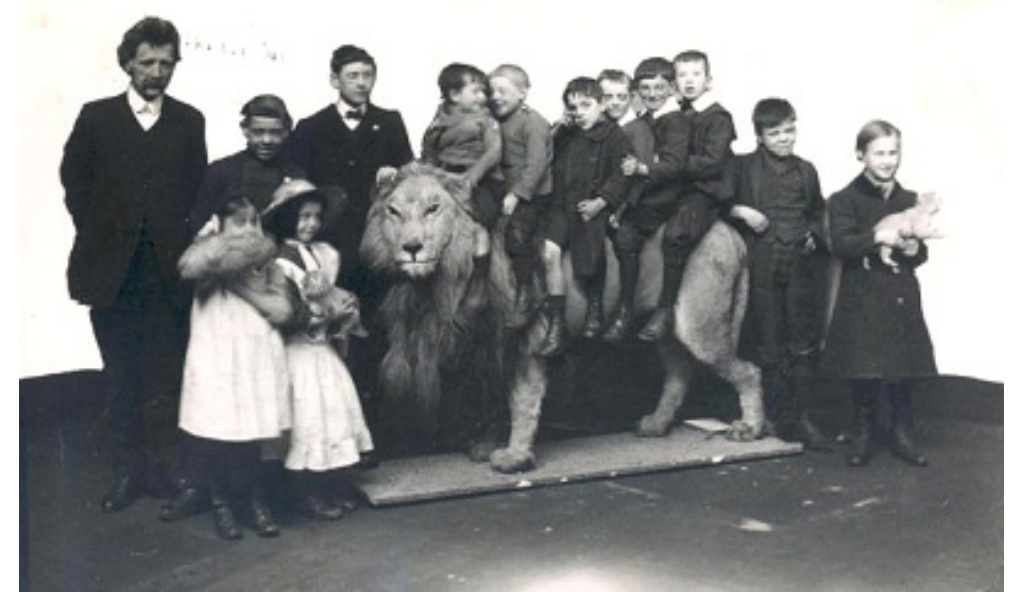

FIGURE 4 - A GROUP OF BLIND CHILDREN FROM SUNDERLAND COUNCIL SCHOOL SITTING ON WALLACE THE LION TO APPRECIATE THE SIZE OF ANIMALS

SOURCE: Copyright Tyne and Wear Archives and Museums.

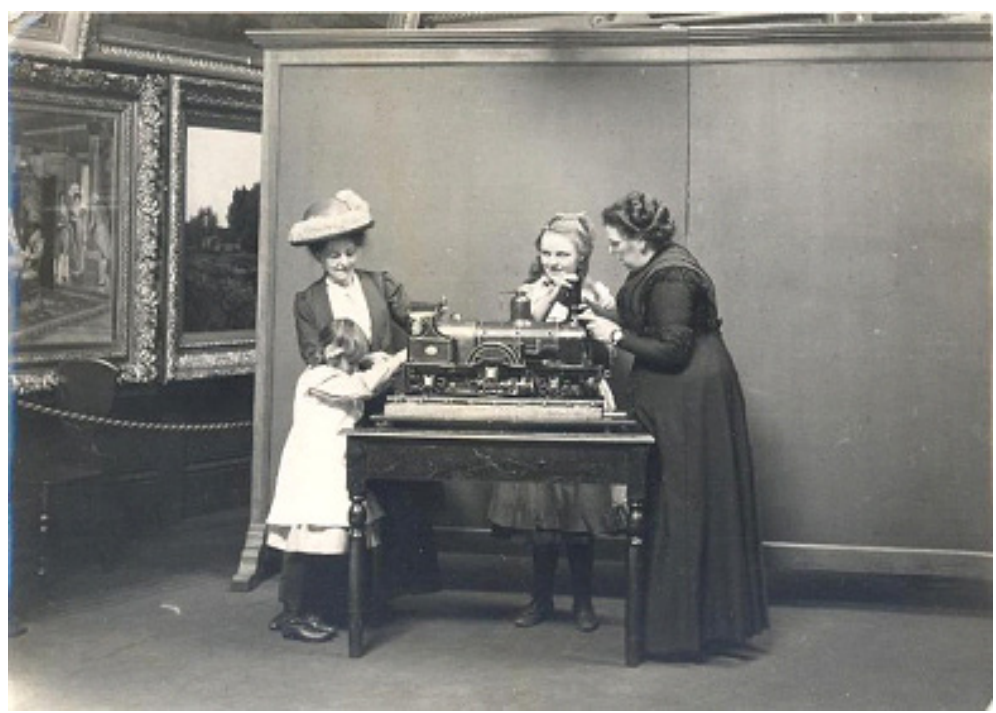

FIGURE 5 - TWO BLIND GIRLS BEING SHOWN A MODEL LOCOMOTIVE BY SIGHTED GUIDES

SOURCE: Copyright Tyne and Wear Archives and Museums. 
Deas concluded his talk by stating that his 'most outstanding impression' of his experiments 'was the discovery of the blindness of the sighted in their relation to the blind'. He criticised the prevailing attitude among the sighted that a person deprived of sight was 'abnormally weak in the other senses' and the tendency to 'swamp' the blind 'with Biblical literature, as though blindness produced a moral leprosy which could be stamped out only in this way' (DEAS, 1913, p. 86-96) His account of his tactile experiments along with seven photographs and some additional evaluative comments by blind educators was published as an article in the Museums Journal, September 1913. One of the blind educators was G. I. Walker who had assisted in delivering the experiments and who commented:

Whatever arouses thought, and stirs interest in form, shape, colour, weight, size, height, depth and the hundred and one accompaniments must inevitably strengthen and quicken the powers of the blind, and therefore tend to fit them to play their parts more efficiently as workers and citizens.

A second educator simply observed, "the new method will help to stimulate our imagination and develop the mental organ of sight ...' (DEAS, 1913, p. 9496) It was not long before other professionals in different performance spaces were responding to Deas' account of his experiments with touch.

\section{'The Blind in the American Museum'}

Knowledge of Deas' work was acknowledged by museum curators at the American Museum, New York in early 1914. The Museum had introduced a programme of activities for the blind in 1909. These activities involved lectures on natural history and some related object handling sessions. The following year an endowment provided funding for loan objects for use with blind children to be sent into New York elementary schools. Loans included ethnographical specimens specifically requested by teachers, Indian or Eskimo clothing, implements and toys. Objects selected, outside their interest value, were chosen with 'regard to form, use and durability of use.' The curators also prepared several small models of large mammals and on reading Deas' article engaged in discussions with trained workers for the blind about the use of such models. Their conclusion was that: 
The child forms a better conception of the animal as a whole, and of the proportion of its parts from the model which he [sic] can hold in his hands. His adjustment to the conception of size may be trained, as is that of the sighted child when regarding maps, pictures and toys. The danger however of the first impression fixing an erroneous conception of size and texture is perhaps greater for the blind than the normal child whose adjustments are more rapid and constant. We propose therefore, both the life size mount and the small model. The child shall first feel the actual specimen, shall realize that it is large, hairy and so forth; then he shall take the model and study the appearance of the animal as a whole, and gain a more definite conception of its proportions. ${ }^{5}$ (AMERICAN MUSEUM JORNAL, January 1914).

One concern of the curators, however, was that blind city children were 'pitiably lacking in "background"' and the most common objects were unknown to them and the appearance of domestic animals, except for cats and dogs, was 'outside their knowledge'. The visit to the museum was for these children more than just an hour's instruction and viewing new objects, it was a 'change of environment, a stimulation of intellectual expression, [and] ... the appreciation of the socializing forces which go to produce public institutions for the distribution of knowledge and the betterment of life'. Perhaps prompted by Deas' article the American Museum curators published an account of their own 'seeing through touch' work in the American Museum Journal in January 1914'. (AMERICAN MUSEUM JORNAL, January 1914) As with Deas' article they included a selection of photographs of visually impaired children engaging with objects.

The reports of tactile experiments in Sunderland and New York naturally prompt thoughts about what other experiences shaped the material world of the visually impaired child? The evolution of technologies associated with enabling the visually impaired child to enter 'the world of the word' and literacy have been documented as part of the new disability history ${ }^{7}$, but what of other apparatus designed to arouse 'thought and stir interests'?

5 'The Blind in the American Museum', American Museum Journal, January 1914 accessed online at http://naturalhistorymag.com January 2013

6 'The Blind in the American Museum', passim

7 See, for example, Oliphant (2008). 


\section{Early Apparatus for Seeing through Touch}

One of the earliest forms of apparatus developed to allow sight through touch was tactile maps. In Mannheim, Germany at the end of the 18th century some experimental maps using various materials, such as pieces of glass and silk threads of various dimensions were produced in small numbers, but proved to be impractical or to tear too easily (McGINNITY; SEYMOUR-FORD; ANDRIES, 2004; COON, 1953). Variations of these tactile maps continued to be developed in the early nineteenth century but were usually custom-made for a few individuals who were blind (McGINNITY, 2004). A significant development was the publication of a limited number of an Atlas of the United State Printed for the Use of the Blind in 1837 for use by children at the New England Institute for the Education of the Blind in Boston (later known as the Perkins Institute). The texts and maps were produced on heavy embossed paper with letters, lines and symbols. ${ }^{8}$ The Institute established a tactile museum of natural objects in 1839 for teaching purposes and Michael Anagnos, the second Director of the Perkins Institute, collected specimens and models from France and across Europe (COON, 1953).

The Perkins Institute was also where Charles Dickens met Laura Bridgman, a deaf-blind child, about who he wrote in American Notes for General Circulation (1842):

Her teacher gives her a new object, for instance, a pencil, first lets her examine it, and get an idea of its use, then teaches her how to spell it by making the signs for the letters with her own finger... The whole of the succeeding year was passed in gratifying her eager inquiries for the names of every object which she could possibly handle; in exercising her in the use of the manual alphabet; in extending in every possible way her knowledge of the physical relations of things... (DICKENS, 1842, p. 4).

The importance of educating the sense of touch using different apparatus was regularly stressed by educational commentators. In the same year that Dickens described Bridgman's tactile and cognitive development John Alston wrote about the activities at the Asylum for the Blind, Glasgow:

${ }^{8}$ Pages from the Atlas can be seen in the David Rumsey Map Collection (2012), www. david.rumsey.com accessed January 2012. 
In order to assist them, it is necessary that the other senses should supply the want of the eye. If, for instance, we wish to teach them the art of reading, letters must be prepared palpable to their touch. If we wish to communicate to them a knowledge of the surface of the earth, globes and maps must be prepared, with the divisions, \&c, \&c, in relief. Knowledge obtained in this way must, of course, be acquired much more slowly than that acquired by sight... (ALSTON, 1842, p. 6).

In $A$ guide to the proper management and education of blind children (1861)' the German educator Johan Georg Knie stressed how important the hands were to the blind:

The hands of a blind person must in, numerous cases, serve him for eyes, therefore, a skilful use of them is of the greatest importance. Should this be neglected in early years it is often impossible to acquire it afterwards... Such neglected children are not only unfit for hand work, or mechanical operations, but also, from not being accustomed to make any good use of the sense of touch, are scarcely capable of applying it to feeling embossed maps... (KNIE, 1861).

He then described in detail how such tactile maps were made:

Maps may be rendered available by puncturing the division lines, \&c, as recommended for letters or geometrical figures. A large puncture for a city, finer ones for smaller towns, and a pressure with a blunt instrument for hills, \&c; or some of this may be done with the thickened gum water. Rivers, or roads may be traced with a blunt point, as before mentioned. A dotting wheel, such as is generally supplied in cases of drawing instruments, run over the lines on the back of the paper, will beautifully emboss diagrams, letters, maps \&c (KNIE, 1861).

Knie's detailed description of tactile mapmaking corresponded with a shift in the availability and breadth of aids for seeing through touch. 


\section{Materiality on Display: the London International Exhibition 1871}

The second half of the nineteenth century saw the emergence in the industrially developed world of international exhibitions which functioned as 'fairs of modernity' where countries displayed their industrial and technological progress and competed with each other 'on the ladder of economic and technical achievements' (ESCOLANO, 2009, p. 34). The exhibitions not only showcased the 'technical, material and scientific achievements of the Industrial Age' but presented advances in education. As Fuchs has written:

This pedagogical impetus was based on the concept of education via direct viewing of the exhibited objects ... entire school buildings and teaching facilities ... [were exhibited] together with technical appliances, machines, specialist textbooks, works written by pupils and students and pedagogical literature... (FUCHS, 2005, p. 52).

The importance associated with these spectacles of display is attested by the number of reports that were issued at intervals 'for the convenience of visitors' during the exhibitions and then re-published in a collected form as a permanent record and circulated to the governments of participating countries. One such collection from 1871 gives details of the 'Educational Works and Appliances' on display at the London International Exhibition. There were twelve separate reports including one by Edmund Johnson ${ }^{9}$ on Methods and Results of Teaching in Schools for the Blind, Deaf, and Dumb.

The report gives detailed descriptions of 'Machines for enabling the blind to correspond' and 'Books, Maps, and Globes, used in their education'. Embossed books from America, France, Germany, Scotland, Italy, Sweden, England and the Netherlands were on display and in addition to giving detailed descriptions of the books and embossing frames and 'printing machines' using the different systems of Lucas, Frere, Moon and Braille, the report describes three pieces of apparatus designed to enable those who had lost their sight at 'a late period of life' and who 'know the form of the various letters' to correspond. For the more affluent the best correspondence apparatus was the 'Noctograph of Messrs. Wedgewood' of Cornhill, England, contained in a 'neat morocco

9 Johnson had previously undertaken an extensive study of musical education for the blind in Europe and America; see Johnson (1855). 
case', it had 'convenient receptacles for carbonised or ordinary paper' and the guidance lines 'are made of wires placed on springs, which easily give way on the slightest pressure, and thus enable the writer to form the lower portion of the letters $g, y$ etc.' The report points to such apparatus also being on display at the Great Exhibition of the Works of Industry of all Nations, London 1851 and also at the London International Exhibition on Art and Industry of 1862 (JOHNSON, 1871).

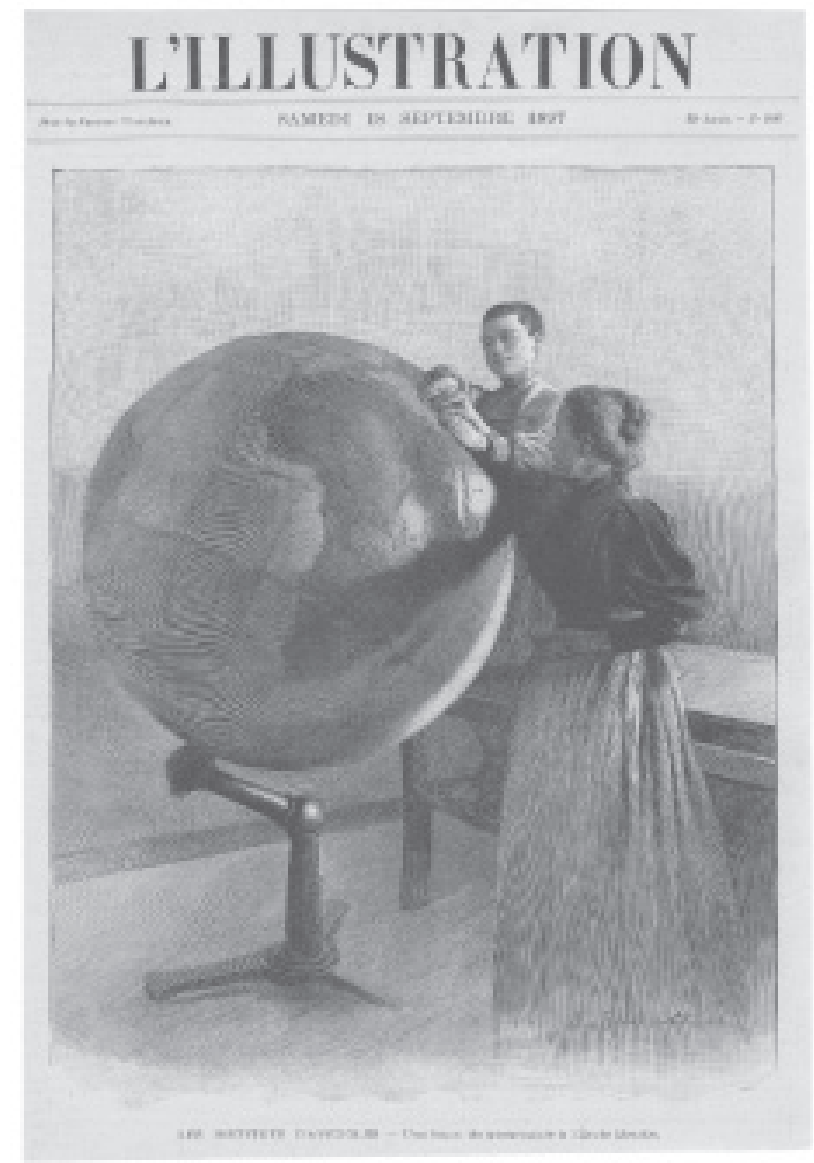

FIGURE 6 - 'UN LEÇON DE GÉOGRAPHIE À L'ÉCOLE BRAILLE', L'ILLUSTRATION, SAMEDI 18 SEPTEMBRE, 1897

SOURCE: Private Collection. 
Reference to earlier international exhibitions also occurs in the section of the report which dealt with 'Globes, Maps and Embossed Figures of Euclid'. On display in 1871 were large terrestrial globes where countries were 'raised in large blocks, their divisions ... indicated by ridges, the rivers and mountains by elevations and depressions, and the chief cities and towns by large and small dots'. Johnson, however, raises a note of caution about the impact of such apparatus of touch by quoting from an earlier report of the Exposition Universelle de Paris, 1867:

Although a blind man may gain a tolerably correct idea of space, form and even colour, few attain a marked proficiency in it. The resources, position and size of countries can be mentally appreciated; but the reduction of large tracts of country to the small scale of a map baffles the blind man more than any other study. The question arises whether he can at all realise by touch, or take in mentally, what the seeing conceive when looking on a flat painted surface. Amongst the English blind this is far from the fact; they learn the names of cities, districts, mountains and rivers, but fail to carry in their mind's eye the whole scheme of a diagrammatized country (JOHNSON, 1871, p. 240).

Nevertheless, Johnson also added that 'persons with highly educated minds and acute sense of touch' had been able to derive considerable advantage from handling embossed maps. Also on display were maps of the World, Europe and France 'embossed by Levitte', an ordinary printed wall map 'marked by different sized strings, gummed on paper, by Mr. Grey of Edinburgh', a small hand globe from Liége and another from Italy (JOHNSON, 1871, p. 241).

A sub-section of the report describes 'Apparatus for mathematical purposes' and the promoters of the Exhibition had selected to display only those appliances which were in daily use amongst pupils in the various blind schools. These appliances included the pentagonal frame where:

[a] slate is formed of a board of about 12 inches by 10 , bound with metal round the edges, and containing 190 pentagonal holes a quarter-of-aninch apart. Into these holes the blind student inserts a five-sided metal pin, which, according to its position and to the end uppermost, represent numerals... (JOHNSON, 1871, p. 241). 
Interestingly, Johnson quotes Sebastien de Guillié, the administrator of the Institution des Jeunes Aveugles, Paris (OLIPHANT, 2006), as stating that 'the privation of sight may be considered an advantage in the study of mathematics ... [as] the blind have a natural disposition for this study, which they follow with a decided taste' (JOHNSON, 1871, p. 239). The idea of the blind having a 'natural disposition' for mathematics was widely held and Johnson cites the example of the 'celebrated blind mathematician', Nicholas Saunderson who held the Chair of Mathematics at the University of Cambridge, which had earlier been held by Sir Isaac Newton. Saunderson, who contracted smallpox as an infant and went blind, held the Chair from 1711 until his death in 1739, was able to perform calculations at high speed on a machine of his own invention and was well know in France (SAUNDERSON, 1740). The reference to Saunderson and Guillié's quote are particularly important as they directly connect to the debates that circulated around 'Molyneux's Problem'. Finally, Sweden and Belgium were the only countries aside from England and Scotland that contributed for display the results of school teaching for the blind. According to Johnson this was a consequence of the 'unsettled state' of continent (JOHNSON, 1871, p. 233-34).

\section{Molyneux's Problem}

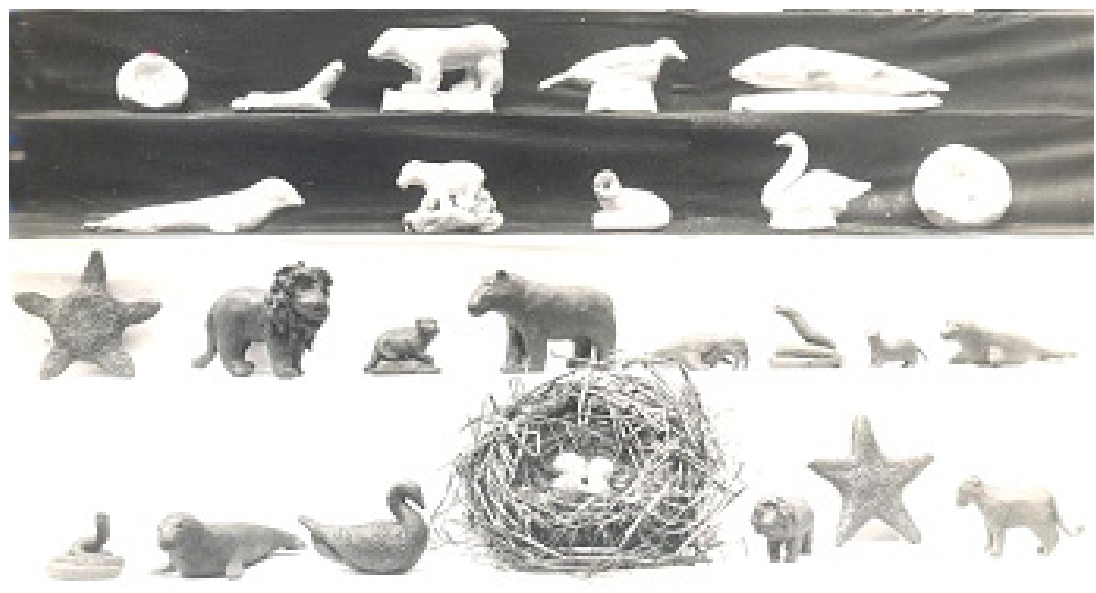

FIGURE 7 - MODELS MADE BY BLIND CHILDREN

SOURCE: Copyright Tyne and Wear Archives and Museums 
Coming back to Deas' photographic evidence of his tactile experiments, he had children who attended the 'seeing through touch' sessions, make clay models five weeks after they had handled objects and then displayed them in cases in the museum alongside photographs of their visits. These were the models which Deas used in his talk to the Museum Association and they were a mechanism for him 'to test the impressions of their visit'(DEAS, 1913, p. 92) He also reported the comments of one teacher on the difficulty that blind children had in understanding the concept of size, 'However carefully the children were informed that their small model of a cow was only one-fortieth the size of the real animal, they were unable to think of the cow as anything larger than the model' (DEAS, 1913, p. 86). Deas in the same section of his talk also recounted the case of a twelve year old blind boy who having recovered his sight after an operation:

[...] for several days following went about in a state of surprise and fear, for almost everything which he had not frequently touched, differed considerably in size from his recollections of seven years ago! The size of his parents alarmed him very much, as he imagined they were much smaller' (DEAS, 1913, p. 86).

What the teacher's observation and the case of the boy who recovered his sight indirectly allude to is the longstanding philosophical debate around what became known as Molyneux's Problem.

In 1688 the Irish savant, William Molyneux put to the English philosopher John Locke a question in the form of a 'thought-experiment':

Suppose a Man born blind, and now adult, and taught by his touch to distinguish between a Cube and a Sphere of the same metal, and nighly of the same bigness, so as to tell, when he felt one and t'other which is the Cube, which is the Sphere. Suppose then the Cube and Sphere placed on a Table, and the Blind Man made to see. Quaere, Whether by his sight, before he touch'd them. He could now distinguish, and tell, which is Globe, which is the Cube (TUNSTALL, 2011, p. 4).

The question was designed to tease out whether the idea of shape gained through touch was the same as the idea of shape gained through sight. Locke, 
in the second edition of his Essay Concerning Human Understanding (1694) determined that:

[...] the Blind Man, at first sight, would not be able with certainty to say which was the Globe, which the Cube, whilst he only saw them; though he could unerringly name them by his touch, and certainly distinguish them by the difference of their Figures felt (LOCKE, 1979, p. 146).

Voltaire and Diderot in their explorations of the 'thought-experiment' drew on the life of the blind mathematician Saunderson, while Descartes explained the relationship between touch and sight by articulating a conception of vision in geometrical terms. All three philosophers helped to create the idea that the 'privation of sight' was 'considered an advantage in the study of mathematics.' Molyneux's Problem continued to be debated throughout the Enlightenment and still continues today (TUNSTALL, 2011; BELL, 2012). In recent years MIT researchers led by Pawan Sinha applied Molyneux's Problem to a group of Indian children treated for cataracts. Initially when these children were given objects to feel and then to identify by sight no 'cross-modal representation' was observed, but within a short time correct identities were established, 'There you have it, Molyneux: "Initially no but subsequently yes". Sinha says. There are certain latencies, it seems, that the brain does possess' (BELL, 2012, p. 25-26).

\section{Photographs, materiality and the internet}

This essay began with an account of how a set of photographs circulated on the internet. It seems appropriate, therefore, to conclude with these photographs, their materiality and their electronic display. Recent work in material culture and a gathering analytical interest in 'socio-material visual practices' has shifted the analytical focus of photographs 'from questions of signification and the analytical translation of meaning into semiotic and linguistic models of apprehension' to 'questions of effect, affect and agency as powerful and active players in a practical mediating role in the social processes' (EDWARDS, 2010, p. 23). Photographs are objects that are handled, exchanged, displayed, and talked about. They engage the emotional and anticipate memory. There is a performative interaction of image and materiality as photographs become 
'active sensory interfaces between referent and viewer' and 'a perpetual movement between touching to see and seeing to touch' to the extent that touch enables seeing and in this way 'bringing about a blurring of the iconic, indexical, and material aspects of the photograph' (EDWARDS, 2010, p. 26).

Meaning making, drawing historical insights from images of the past, is also directly connected with where the images are viewed - the spaces where a dialogue with the visual occurs. It also follows that if we agree that the meaning $[\mathrm{s}]$ we take from images are always framed by the context in which we come upon them, then there is also a need to examine and detail the life of an image' [or as Elizabeth Edwards terms it, the social biography (EDWARDS, 2001, p. 13-16) of an image] to consider its circulation and its currency 'as it moves through time and space from context to context' (WALKER, 1997, p. 57). The properties of an image do not change, but over its material existence it accumulates and accrues different meanings as it enters into relationships with new contexts and audiences. From the moment of their creation the social biography of the Sunderland photographs has involved their display and storage in the museum, their migration into Tyne and Wear Archives and their consequent accessioning as individual items in a catalogue and placement in a solander box and more recently their digitisation and submergence in 'an incomprehensibly huge, rapidly expanding virtual archive of historical and geographic knowledge' of which no one will ever be familiar with more than a fraction (MITCHELL, 2003 , p. 302). With each step the photographs will have been recontextualised, and as the context changes so does the meaning. The 'truth' value of photographs is fluid depending upon the context in which they are viewed. ${ }^{10}$

Further, with the distributed information flows of the internet it follows that the sensory and emotional significance of the photographs have been dispersed. Digitisation has enabled greater access but removing the tactile experience and replacing it with reading images on screen it can be argued has created a sense of loss, a further distancing from the past (GROSVENOR, 2010, p. 160). There is, of course, a counter argument that placing them on the internet has at the same time involved the emergence of new sensory and embodied practices, new registers of touch, as Elizabeth Edwards writes, 'the proxemics of viewing in groups around a screen, the finger on the keyboard, the sweeping movement of the mouse, the flicker of the screen or the stroking movements of the touch screen'. Whatever, the argument photographs project in all their forms a 'present becoming past into the future' (EDWARDS, 2010, p. 32, 23).

${ }^{10}$ See Grosvenor (2010). 


\section{REFERENCES}

ALSTON, J. Statements of the Education, Employments and Internal Arrangements Adopted at the Asylum for the Blind. Glasgow: John Smith and Son Booksellers, 1842.

BELL, Julian. The Irish Savant's Problem. London Review of Books, p. 25-26, 21 June 2012.

COON, Nelson. The place of the museum in the education of the blind. New York: American Foundation for the Blind, 1953.

DEAS, J. A. Charlton. 'The Showing of Museums and Art Galleries to the Blind'. The Museums JournaL, 13, 3, p. 89, Sept. 1913,.

DESCARTES, Rene. 'La Dioptrique'. In: TUNSTALL, Kate E. Blindness and Enlightenment. An Essay. New York: Continuum Books, 2011. p. 59.

DICKENS, Charles. American Notes for General Circulation. [s.l.]: Chapman and Hall, 1842.

EDWARDS, Elizabeth. Photographs and History. Emotion and Materiality. In: DUDLEY, Sandra H. (Ed.). Museum Materialities. London: Routledge, 2010.

. Raw Histories. Photographs, Anthropology and Museums. Oxford: Berg, 2001. p. 13-16.

ESCOLANO, Agustin. Ethnohistory and Materiality of Education: in the setting of the Universal Exhibitions. In: LAWN, Martin. Modelling the Future. Exhibitions and the Materiality of Education. Oxford: Symposium Books, 2009.

FUCHS, Eckhardt. All the World into the School: World's Fairs and the emergence of the school museum in the nineteenth century. In: LAWN, Martin; GROSVENOR, Ian. Materialities of Schooling. Oxford: Symposium Books, 2005,

GROSVENOR, Ian. The school album: images, insights and inequalities. Educació $i$ Història, 15, p. 155-156, 2010.

. Back to the Future or towards a sensory history of schooling. History of Education, 41, 5, p. 675-688, 2012.

JOHNSON, E. C. An Inquiry into the Musical Instruction of the Blind in France, Spain and America. London: John Mitchell, 1855.

JOHNSON, Edmund. Methods and Results of Teaching in Schools for the Blind, Deaf, and Dumb. In: HOUGHTON, Lord (Ed.). London International Exhibition, 1871. Official Reports on the Various Sections of the Exhibition. Woolen Fabrics and Machinery, Education, Scientific Inventions. London: J M. Johnson \& Sons, 1871. v. II, p. 234-239.

KNIE, J. G. A guide to the proper management and education of blind children. Tr. by W. Taylor, Fourth Edition. London: Simpkin, Marshall \& Co, 1861. x, 22, p. 35 
KUDLICK, Catherine J. Disability History: Why We Need Another “Other”. American Historical Review, 108, p. 763-793, June 2003.

LAWN, Martin; GROSVENOR, Ian. Materialities of Schooling. Oxford: Symposium Books, 2005.

LOCKE, John. An Essay Concerning Human Understanding. ed. Peter H. Nidditch. Oxford: Oxford University Press, 1979.

MCGINNITY, B. L.; SEYMOUR-FORD, J.; ANDRIES, K. J. Geography. Watertown, MA: Perkins History Museum for the Blind, 2004.

MITCHELL, William. J. Wunderkammer to World Wide Web: Picturing Place in the PostPhtographic Era. In: SCHWARTZ, Joan M.; RYAN, James R. (Eds.). Picturing Place. Photography and the Geographical Imagination. London: I. B. Tauris, 2003. p. 302.

OLIPHANT, John. Empowerment and Debilitation in the Educational Experience of the Blind in Nineteenth-century England and Scotland. History of Education, 35, 1, p. $51,2006$.

. "Touching the Light": the invention of literacy for the blind'. Paedagogica Historica, 44, 1\&2, p. 67-82, 2008.

SAUNDERSON, London: Rivers Oram Press, 1997. p. 57.

Nicholas. The Elements of Algebra, in Ten Books: by Nicholas Saunderson LL.D. Late Lucasian Professor of Mathematics in the University of Cambridge, and Fellow of the Royal Society. To which is prefixed, an account of the author's life and character, collected from his oldest and most intimate acquaintances, 2 volumes. Cambridge: Cambridge University Press, 1740.

TUNSTALL, Kate E. Blindness and Enlightenment. An Essay. New York: Continuum Books, 2011.

THE BLIND IN THE AMERICAN MUSEUM. American Museum Journal, January 1914. Accessed online at http://naturalhistorymag.com January 2013.

WALKER, John A. Context as a Determinant of Photographic Meaning. In: EVANS, J. (Ed.). The Camerawork Essays. Context and Meaning in Photographs.

Texto recebido em 15 de novembro de 2012.

Texto aprovado em 26 de fevereiro de 2013. 